\title{
Review Article \\ Regulatory T Cell in Stroke: A New Paradigm for Immune Regulation
}

\author{
Sheng Chen, ${ }^{1,2}$ Haijian Wu, ${ }^{1}$ Damon Klebe, ${ }^{2}$ Yuan Hong, \\ Jianmin Zhang, ${ }^{1}$ and Jiping Tang ${ }^{2}$ \\ ${ }^{1}$ Department of Neurosurgery, Second Affiliated Hospital, School of Medicine, Zhejiang University, Hangzhou, Zhejiang 310009, China \\ ${ }^{2}$ Department of Physiology and Pharmacology, Loma Linda University, Loma Linda, CA 92350, USA
}

Correspondence should be addressed to Jianmin Zhang; zjm135@vip.sina.com and Jiping Tang; jtang@llu.edu

Received 30 April 2013; Accepted 4 July 2013

Academic Editor: Carlos Barcia

Copyright (C) 2013 Sheng Chen et al. This is an open access article distributed under the Creative Commons Attribution License, which permits unrestricted use, distribution, and reproduction in any medium, provided the original work is properly cited.

Stroke is a common, debilitating trauma that has an incompletely elucidated pathophysiology and lacks an effective therapy. FoxP $3^{+} \mathrm{CD} 25^{+} \mathrm{CD}^{+}$regulatory $\mathrm{T}$ cells (Tregs) suppress a variety of normal physiological and pathological immune responses via several pathways, such as inhibitory cytokine secretion, direct cytolysis induction, and antigen-presenting cell functional modulation. FoxP $3^{+} \mathrm{CD} 25^{+} \mathrm{CD} 4^{+}$Tregs are involved in a variety of central nervous system diseases and injuries, including axonal injury, neurodegenerative diseases, and stroke. Specifically, FoxP $3^{+} \mathrm{CD} 25^{+} \mathrm{CD} 4^{+}$Tregs exert neuroprotective effects in acute experimental stroke models. These beneficial effects, however, are difficult to elucidate. In this review, we summarized evidence of FoxP3 ${ }^{+} \mathrm{CD} 25^{+} \mathrm{CD} 4^{+}$Tregs as potentially important immunomodulators in stroke pathogenesis and highlight further investigations for possible immunotherapeutic strategies by modulating the quantity and/or functional effects of FoxP3 ${ }^{+} \mathrm{CD} 25^{+} \mathrm{CD} 4^{+}$Tregs in stroke patients.

\section{Introduction}

Regulatory T cells (Tregs) play pivotal roles in the maintenance of immunological self-tolerance and immune homeostasis [1-3]. Tregs are involved in both normal physiological and pathological suppression of immune reactivity $[2,4]$, including autoimmune diseases, inflammatory disorders, transplant rejection, tumorigenesis, and infections [5-8]. There are several subpopulations of Tregs, such as FoxP $3^{+} \mathrm{CD} 25^{+} \mathrm{CD} 4^{+}$Tregs, interleukin-10- (IL-10-) producing "Trl” cells, transforming growth factor- $\beta$ - (TGF- $\beta$-) producing T-helper type 3 cells, $\mathrm{CD} 8^{+} \mathrm{T}$-suppressor cells, natural killer T cells, $\mathrm{CD}^{-} \mathrm{CD}^{-} \mathrm{T}$ cells, and $\gamma \delta \mathrm{T}$ cells [2]. Specifically, FoxP $3^{+} \mathrm{CD} 25^{+} \mathrm{CD} 4^{+}$Tregs acquired notable attention because of their role in a variety of central nervous system (CNS) and autoimmune pathologies, such as multiple sclerosis (MS), stroke, and glioblastomas [9-13].

Stroke is a leading cause of death and disability worldwide $[14,15]$. Although great efforts have been made, effective therapeutic methods for significantly improving functional outcomes of stroke patients are lacking [16]. Unfortunately, our current understanding of stroke pathogenesis is incomplete [17]. Further elucidation of the pathophysiological mechanisms in stroke trauma will be of great importance.

Immunity and inflammation are key elements in the pathological progression of stroke $[18,19]$. The immune and inflammatory responses are involved in both acute brain injury and subsequent brain rehabilitation after stroke, and stroke-induced insult could adversely affect the function of the peripheral immune system [20-23]. On the one side, active immune cells amplify cellular damage within the injured brain parenchyma $[18,24,25]$. On the other side, they induce tissue reconstruction and repair via removing dead cells and debris, developing an anti-inflammatory milieu and generating prosurvival factors [26]. Particularly, studies reported that FoxP3 ${ }^{+} \mathrm{CD} 25^{+} \mathrm{CD} 4^{+}$Tregs are important neuroprotective immunomodulators in stroke, but their contributive effects towards stroke pathophysiology are still controversial [12, 27, 28]. Although many review articles have focused on FoxP3 ${ }^{+} \mathrm{CD} 25^{+} \mathrm{CD} 4^{+}$Tregs $[9,29,30]$, a new 
review is necessary for appraising recent research advances in FoxP $3^{+} \mathrm{CD} 25^{+} \mathrm{CD} 4{ }^{+}$Tregs after stroke. The objectives of this review are (1) survey the evidence of the vital roles played by FoxP $3^{+} \mathrm{CD} 25^{+} \mathrm{CD} 4^{+}$Tregs in stroke pathophysiology, (2) discuss further investigations to fully elucidate the precise regulatory mechanisms of FoxP $3{ }^{+} \mathrm{CD} 25^{+} \mathrm{CD} 4{ }^{+}$Tregs in stroke, and (3) evaluate the possible therapeutic application and potential pitfalls of modulating the activity and quantity of FoxP $3^{+} \mathrm{CD} 25^{+} \mathrm{CD} 4^{+}$Tregs in stroke treatment.

\section{The Identification and Immunosuppressive Mechanisms of FoxP3 ${ }^{+} \mathrm{CD}^{+} 5^{+} \mathrm{CD4}^{+}$Tregs in CNS Diseases}

2.1. The Identification of FoxP $3^{+} \mathrm{CD} 25^{+} \mathrm{CD} 4^{+}$Tregs. Molecular markers are essential tools for defining Tregs. Various Treg markers include interleukin-2 receptor (CD25), cytotoxic Tlymphocyte-associated antigen-4 (CTLA-4), glucocorticoidinduced tumor necrosis factor receptor family-related gene (GITR), lymphocyte activation gene-3 (LAG-3), CD127, and fork head transcription factor box P3 (FoxP3) [31, 32]. Identification of Tregs, however, remains problematic because some evidence suggests the above listed Treg markers are not strictly Treg specific and also appear to be expressed on other T lymphocytes $[31,32]$. Currently, FoxP3 ${ }^{+} \mathrm{CD} 25^{+} \mathrm{CD} 4^{+}$ Tregs are distinguished by their expression of CD25 and the transcription factor FoxP3 $[33,34]$. FoxP $3^{+} \mathrm{CD} 25^{+} \mathrm{CD} 4^{+}$ Tregs mainly arise from progenitor cells in the bone marrow and develop in the thymus through the course of positive and negative selection [1]. These natural FoxP $3{ }^{+} \mathrm{CD} 25^{+} \mathrm{CD} 4^{+}$ Tregs constitute approximately $5-10 \%$ of peripheral $\mathrm{CD} 4^{+}$ $\mathrm{T}$ cells in both humans and mice [35]. FoxP $3^{+} \mathrm{CD} 25^{+} \mathrm{CD} 4^{+}$ Tregs are also induced in the periphery from conventional naive $\mathrm{CD}^{+} \mathrm{T}$ cells following antigenic stimulation under certain conditions $[1,6]$. CD25 is primarily described as a Treg marker because Tregs constitutively express high levels of CD25 and are dependent on IL-2 for their proliferation and survival $[33,36,37]$. Nevertheless, CD25 is not unique to Tregs since it is also expressed on activated effector $\mathrm{T}$ cells [38]. Subsequent studies reported that transcription factor FoxP3 was an exclusive intracellular marker and a key player in Tregs development and function, especially for natural FoxP ${ }^{+} \mathrm{CD} 25^{+} \mathrm{CD} 4{ }^{+}$Tregs [39-41]. FoxP3 inhibited transcriptional activation by forming both DNA-protein and protein-protein complexes with molecular targets [42, 43]. FoxP3 blocks activation of two key transcription factors, namely, nuclear factor $-\kappa \mathrm{B}(\mathrm{NF}-\kappa \mathrm{B})$ and nuclear factor of activated $\mathrm{T}$ cells (NF-AT), which are essential for cytokine gene expression and normal functioning of target $\mathrm{T}$ cells, and FoxP3 also antagonizes cAMP-responsive-element-bindingprotein- (CREB-) dependent gene expression [42-44]. The functional significance of FoxP3 for Treg activity is further supported by such findings as the following: loss of FoxP3 function caused autoaggressive lymphocyte proliferation, whereas excessive FoxP3 expression resulted in severe immunodeficiency [45]. Moreover, some people with a mutation in the FoxP3 gene have multisystem autoimmune diseases with fatal consequences [41]. But the specificity of FoxP3 for Tregs is challenged by the discovery of FoxP3 expression in other cells [46]. Thus, a more reliable and unambiguous marker for FoxP3 ${ }^{+} \mathrm{CD} 25^{+} \mathrm{CD} 4^{+}$Tregs is still needed.

2.2. The Immunosuppressive Mechanisms of FoxP $3^{+} \mathrm{CD} 25^{+} \mathrm{CD} 4^{+}$Tregs. The exact mechanisms of FoxP $3^{+} \mathrm{CD} 25^{+} \mathrm{CD} 4^{+}$Tregs in the immune response are still not well defined. First, Tregs are characterized by their constitutive expression of CTLA-4, a cell surface marker, suggesting that this marker constitutes a core mechanism driving immune suppression [47]. CTLA-4 x Ig convert naive $\mathrm{CD} 4^{+} \mathrm{CD} 25^{-} \mathrm{T}$ cells into $\mathrm{CD} 4^{+} \mathrm{CD} 25^{+}$Tregs, which depends on B7-2 signaling from antigen-presenting cell (APC) [48]. CTLA-4 is demonstrated to be an important factor in Treg function [49-51], and CTLA-4 deficiency in Tregs is sufficient to decrease their immunosuppressive function in vivo and in vitro, which is partly mediated by downregulating CD80 and CD86 on APCs [52-55]. In addition, it is entirely expected that FoxP3 ${ }^{+} \mathrm{CD} 25^{+} \mathrm{CD} 4^{+}$Tregs exerted immune inhibitory effects via several CTLA4-independent pathways, such as secretion of inhibitory cytokines in peripheral blood and brain, like TGF- $\beta$, IL-10, and IL-35; granzyme/perforinmediated cytolysis; and direct modulation of APC function $[1,2,30]$. TGF- $\beta$, a multifunctional cytokine, may exert pivotal functions in maintaining immune homeostasis and suppressing autoimmunity $[56,57]$. TGF- $\beta$ plays an important role in FoxP3 expression, FoxP $3^{+} \mathrm{CD} 25^{+} \mathrm{CD} 4^{+}$ Treg differentiation, and Treg-mediated immune suppression [57-60]. In addition, FoxP $3^{+} \mathrm{CD} 25^{+} \mathrm{CD} 4^{+}$Treg-secreted IL10 is another key anti-inflammatory cytokine that provides neuroprotective effects after cerebral ischemia [61, 62]. IL-10 can inhibit inflammatory responses and limit inflammationmediated unnecessary tissue damage [63]. More recently, Li et al. demonstrated Treg administration after ischemic stroke decreased infiltrated peripheral immune cells and reduced neutrophil MMP-9 production, ameliorating blood-brain barrier disruption as a result [64].

To become functional, FoxP $3^{+} \mathrm{CD} 25^{+} \mathrm{CD} 4^{+}$Tregs may require activation through $\mathrm{T}$ cell receptor (TCR) [37]. Once activated, they suppress in an antigen nonspecific manner $[2,65]$. This phenomenon of $\mathrm{FoxP}^{+} \mathrm{CD} 25^{+} \mathrm{CD} 4^{+}$Tregmediated immunosuppression is known as "bystander suppression" [2]. Through the processes of bystander suppression, FoxP $3^{+} \mathrm{CD} 25^{+} \mathrm{CD} 4^{+}$Tregs effectively suppress various immune responses [2].

\subsection{The Role of FoxP3 ${ }^{+} \mathrm{CD} 25^{+} \mathrm{CD} 4^{+}$Tregs in CNS Diseases.} The importance of FoxP $3^{+} \mathrm{CD} 25^{+} \mathrm{CD} 4^{+}$Tregs in regulating and maintaining homeostasis between both the immune system and the brain is demonstrated by their roles in CNS diseases, especially neurodegenerative diseases, such as MS, Parkinson's disease (PD) and Alzheimer's disease (AD) [9, $10,66,67]$. Dysfunction of FoxP $3^{+} \mathrm{CD} 25^{+} \mathrm{CD} 4^{+}$Tregs was observed in the early stages of several neurodegenerative diseases [10]. The loss of immunosuppressive activity from $\mathrm{CD} 25^{+} \mathrm{CD} 4^{+}$Tregs has been described in MS patients [68]. Adoptive transfer of $\mathrm{CD} 25^{+} \mathrm{CD} 4^{+}$Tregs conferred significant protection against EAE induction and progression, 
which was associated with $\mathrm{CD} 25^{+} \mathrm{CD} 4^{+}$Treg-mediated promotion of the protective Th2 immune response and prevention of CNS inflammation via upregulation of specific adhesion molecules [69]. In the 1-methyl-4-phenyl-1,2,3,6tetrahydropyridine (MPTP-) intoxicated mouse model of $\mathrm{PD}$, adoptive transfer of $\mathrm{CD} 3$-activated $\mathrm{CD} 25^{+} \mathrm{CD} 4^{+}$Tregs alleviated microglial-mediated inflammation and promoted expression of astrocyte-derived brain-derived neurotrophic factor and glial cell line-derived neurotrophic factor, thus conferring neuroprotective effects [70]. Additionally, proteomic studies reported that $\mathrm{CD} 25^{+} \mathrm{CD} 4^{+}$Tregs altered the microglial proteome, which was linked to cell metabolism, migration, protein transportation and degradation, redox biology, cytoskeletal modulation, and bioenergetic activities, thus beneficially altering microglia in response to nitrated $\alpha$ synuclein and slowing the progression of PD [71].

Research demonstrated, however, that FoxP3 ${ }^{+} \mathrm{CD} 25^{+} \mathrm{CD}^{+}$Tregs might inhibit the beneficial immune responses in CNS diseases [72, 73]. Kipnis et al., demonstrated that depletion of $\mathrm{CD} 25^{+} \mathrm{CD} 4^{+}$Tregs enhanced a $\mathrm{T}$ cell-mediated protective immune response and, hence, improved neuronal survival after CNS injury in a mouse model [74]. CD25 ${ }^{+} \mathrm{CD} 4^{+}$Tregs could exert both beneficial and detrimental effects in neuronal survival after injury [73]. The actual role of $\mathrm{CD} 25^{+} \mathrm{CD} 4^{+}$Tregs in neurodegeneration might correlate with the different immune statuses of individuals [73].

Treg-mediated antioxidative effects may be vitally important neuroprotective mechanisms. FoxP $3^{+} \mathrm{CD} 25^{+} \mathrm{CD} 4^{+}$Tregs suppressed microglial reactive oxygen species (ROS) production, suggesting Tregs conferred neuroprotection against microglial neurotoxic responses through their antioxidative effects [70]. In a murine model of HIV-1-associated neurodegeneration, $\mathrm{CD} 25^{+} \mathrm{CD} 4^{+}$Tregs also significantly reduced ROS production in virally infected bone marrow-derived macrophages and promoted neuronal survival [75].

In summation, these findings demonstrated that FoxP $3^{+} \mathrm{CD} 25^{+} \mathrm{CD}^{+}$Tregs play a possible vital role in the pathogenesis of CNS diseases, whereas the detailed function of FoxP3 $3^{+} \mathrm{CD} 25^{+} \mathrm{CD} 4^{+}$Tregs in these diseases is still inconclusive and requires further exploration.

\section{FoxP3 ${ }^{+} \mathrm{CD}^{+}{ }^{+} \mathrm{CD4}^{+}$Tregs in Stroke}

Our understanding of FoxP $3^{+} \mathrm{CD} 25^{+} \mathrm{CD} 4^{+}$Tregs in stroke has advanced considerably, based on the following key findings (Figure 1). These new insights have not only been provided from animal models, but also from clinical studies in stroke (Table 1). Uncertainties, however, remain in $\mathrm{FoxP}^{+} \mathrm{CD} 25^{+} \mathrm{CD}^{+}$Tregs, such as their real functions, specific targets, and underlying mechanisms. Further exploration for answers to these questions may yield more sophisticated and pleiotropic therapeutics for stroke treatment.

3.1. The Poststroke Temporal and Spatial Dynamics of FoxP $3^{+} \mathrm{CD} 25^{+} \mathrm{CD}^{+}$Tregs. Identification of the poststroke temporal and spatial distribution of $\mathrm{FoxP}^{+} \mathrm{CD} 25^{+} \mathrm{CD} 4^{+}$ Tregs has assisted in elucidating their roles in stroke. In a middle cerebral artery occlusion (MCAO) murine model,
Gelderblom et al. demonstrated less than $5 \%$ of FoxP3 $^{+} \mathrm{T}$ cells $\left(\mathrm{CD}^{+} 4.2 \%, \mathrm{CD}^{+} 1.3 \%\right)$ are observed in the ipsilesional hemisphere 3 days after reperfusion; however, a high proportion of FoxP3 ${ }^{+} \mathrm{CD} 4^{+}$and $\mathrm{FoxP}^{+} \mathrm{CD}^{+}$lymphocytes was found in the spleen [76]. Further studies reported that FoxP $3^{+} \mathrm{CD} 25^{+} \mathrm{CD} 4^{+}$Tregs were detected in the ipsilateral hemisphere at 3 days after MCAO by using flow cytometric analysis, and they became visibly restricted to the peri-infarct zone in immunohistochemically stained brain sections at 5 days after MCAO [12]. Additionally, a clinical study with a total of 67 subjects ( 25 of them with acute ischemic stroke) observed amplified $\mathrm{T}$ and $\mathrm{B}$ cell activation as well as an increased number of $\mathrm{CD} 25^{+} \mathrm{CD} 4^{+}$Tregs in the peripheral blood of patients after acute ischemic stroke in comparison to age-matched healthy controls and patients with other neurological diseases [77]. Although these findings in stroke patients are noteworthy, they should be cautiously extrapolated, due to the small sample size, relatively mild disease severity, and lack of assessment of the effects from other risk factors, such as diabetes, hypertension, drinking, and smoking, on the observed results [77]. Another prospective study in 46 consecutive patients with acute stroke, however, reported that increased apoptosis correlated with a decline in $\mathrm{FoxP}^{+} \mathrm{CD} 25^{+} \mathrm{CD} 4^{+}$Tregs and other types of immune cells (e.g., Th, CTL, and B cells) after stroke, but decreased FoxP3 ${ }^{+} \mathrm{CD} 25^{+} \mathrm{CD} 4^{+}$Tregs did not show any correlation with the development of infections or stroke outcomes [78]. Similarly, potential limitations of the present study, such as the influence of therapies on immune system function and a relatively small sample size, should not be neglected. Also, the proportions of both activated T cells and FoxP $3^{+} \mathrm{CD} 25^{+} \mathrm{CD}^{+}$Tregs were increased up to 3 weeks in the peripheral blood following acute ischemic stroke, whereas the suppressive effects of $\mathrm{FoxP}^{+} \mathrm{CD} 25^{+} \mathrm{CD} 4^{+}$Tregs from stroke patients on $\mathrm{T}$ cell proliferation were markedly reduced in female subjects [79]. In addition, significant differences between male and female stroke patients in the frequency and suppressive effects of FoxP $3^{+} \mathrm{CD} 25^{+} \mathrm{CD} 4^{+}$Tregs were demonstrated in this study, but the underlying reasons for these observed differences are unknown [79]. The lack of a substantial number of severe stroke patients in this study, however, may deceptively lead to overlooking the effects of stroke severity on the number of FoxP $3^{+} \mathrm{CD} 25^{+} \mathrm{CD} 4^{+}$Tregs. Furthermore, investigations concentrating on the long-term modulation and activation of the immune system following stroke showed that a strong accumulation and proliferation of $\mathrm{FoxP}^{+} \mathrm{CD} 25^{+} \mathrm{CD} 4^{+}$Tregs in the ischemic hemisphere were observed in the late phase (peaked around 14 days and lasted up to 30 days) [80]. This paralleled with the observed increased number of $\mathrm{MHCII}^{+}$microglia, suggesting microglia are relevant in maintaining Tregs at late time points after MCAO [80]. Recently, an ex vivo analysis demonstrated that both $\mathrm{T}$ cell receptor stimulation-induced $\mathrm{CD} 4^{+} \mathrm{T}$ cell proliferation and $\mathrm{CD} 25^{+} \mathrm{CD} 4^{+}$Treg-mediated immunosuppression were unchanged, whereas costimulatory efficacy (verified in animal models) of circulating costimulatory cells decreased within the first three days after experimental and human ischemic stroke onset, indicating the decrease in circulating costimulatory cells may be responsible for 


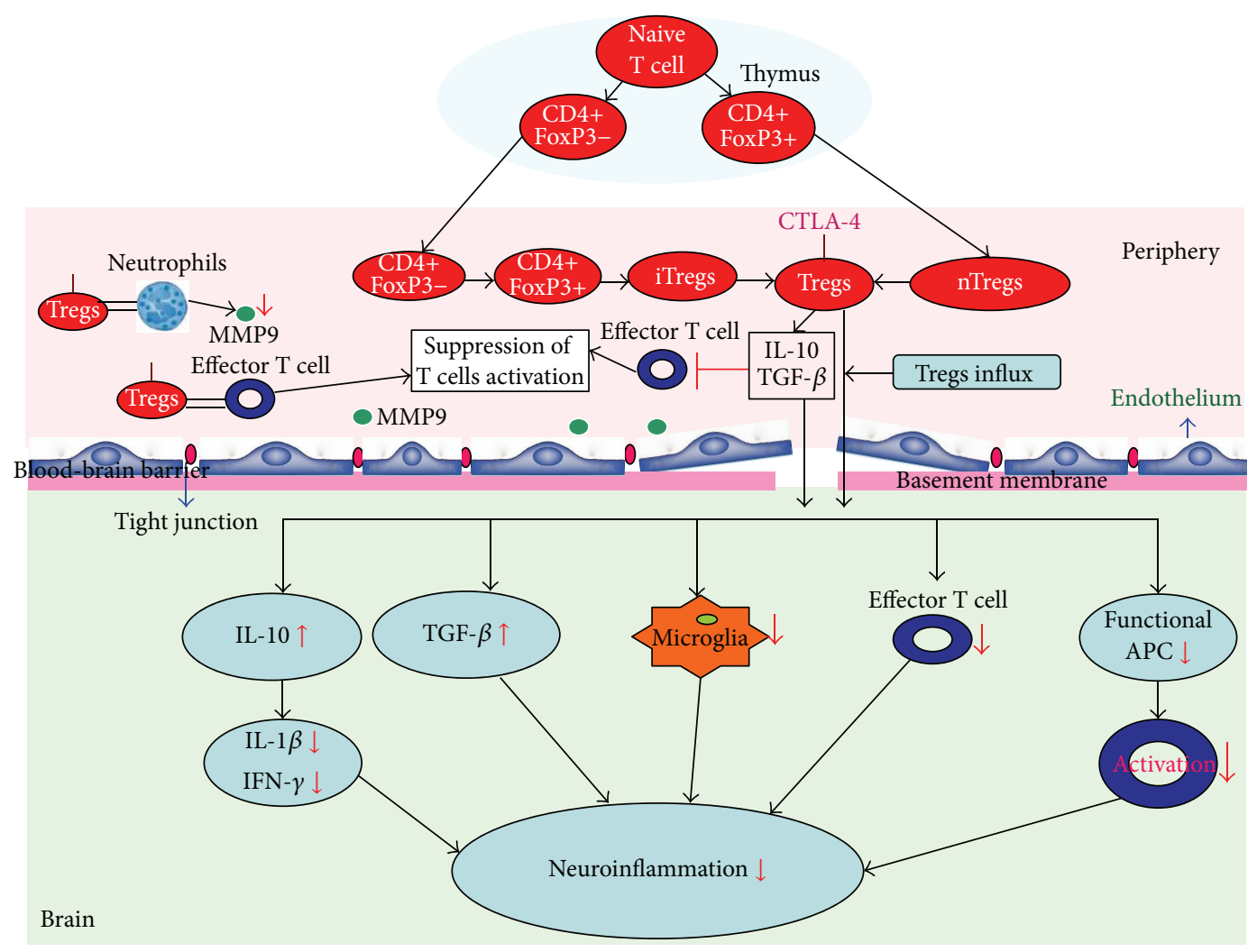

Figure 1: FoxP $3^{+} \mathrm{CD} 25^{+} \mathrm{CD} 4^{+}$Tregs in the pathogenesis of stroke. Both natural and induced FoxP $3^{+} \mathrm{CD} 25^{+} \mathrm{CD} 4^{+}$Tregs migrate into the brain parenchyma after stroke. The functional roles of FoxP $3^{+} \mathrm{CD} 25^{+} \mathrm{CD} 4^{+}$Tregs in modulation of neuroinflammation after stroke, including (1) secreting anti-inflammatory cytokines to decrease proinflammatory cytokines in periphery and brain, such as transforming growth factor$\beta$ (TGF- $\beta$ ) and interleukin-10 (IL-10); (2) reducing Matrix metallopeptidase 9 (MMM-9) to prevent blood-brain barrier disruption; (3) suppressing effector $\mathrm{T}$ cell both in periphery and brain; (4) inhibiting the activation of microglia. FoxP $3{ }^{+} \mathrm{CD} 25^{+} \mathrm{CD} 4{ }^{+}$Tregs suppress the detrimental inflammatory responses after stroke.

stroke-induced immunosuppression [81]. The brain-specific subset of costimulatory cells in this study, however, must be identified and verified in future studies. Moreover, a randomized, prospective clinical cohort study of seven hundred subjects in the cardiovascular unit of the Malmö Diet and Cancer Study declared that no correlation exists between low levels of circulating $\mathrm{FoxP}^{+} \mathrm{CD} 25^{+} \mathrm{CD} 4^{+}$Tregs and an increased risk for stroke development, suggesting more heterogeneous causes of this disease [82]. These findings should be cautiously interpreted due to the technical difficulties in defining human FoxP $3^{+} \mathrm{CD} 25^{+} \mathrm{CD} 4^{+}$Tregs in that study [82]. Altogether, the temporal and spatial dynamics of FoxP $3^{+} \mathrm{CD} 25^{+} \mathrm{CD} 4^{+}$Tregs after stroke are still controversial. More studies are required to further clarify the distribution of FoxP $3^{+} \mathrm{CD} 25^{+} \mathrm{CD} 4^{+}$ Tregs in the CNS, peripheral blood, and lymphatic organs at different phases following stroke.

\subsection{The Roles and Relevant Mechanisms of} FoxP $3^{+} \mathrm{CD} 25^{+} \mathrm{CD} 4^{+}$Tregs in Stroke. Numerous studies indicated that FoxP $3^{+} \mathrm{CD} 25^{+} \mathrm{CD} 4^{+}$Tregs play multiple key roles in CNS postischemic injury as immunomodulators, including regulating the immune inflammatory response, limiting lesion development, and promoting tissue repair. Early studies showed that the possible production of Tregs occurs after repetitive stimulation by low-dose antigen with active tolerance $[83,84]$. These cells modulated the immune response and alleviated focal ischemic brain injury in a permanent MCAO rat model by secreting anti-inflammatory cytokines (e.g., TGF- $\beta 1$, and IL-10) [85]. Subsequent research observed that preischemia induction of immunologic tolerance to brain antigen myelin basic protein (MBP) induced a regulatory $\mathrm{T}$ cell response, which prevented development of a deleterious autoimmune response (Th1 response) to this antigen and eventually improved outcomes after transient MCAO [86, 87]. Specifically, animals with a regulatory response to $\mathrm{MBP}$ in the spleen showed decreased inflammation and an increased number of FoxP3 positive cells in the ischemic hemisphere [87]. In addition, a previous study indicated that E-selectin-specific FoxP $3^{+} \mathrm{CD} 4^{+}$Tregs increase neurogenesis efficacy and promote sensory-motor functional recovery after ischemic brain injury [88].

In 2006, after evaluating the effects of postischemic brain damage on the peripheral immune system, Offner et al. observed an increased percentage of FoxP3 ${ }^{+} \mathrm{CD} 4^{+}$ Tregs, macrophages, and dendritic cells in the blood and spleen at 96 hours after ischemic injury [89]. Additionally, a drastic loss of splenocytes (relatively selective reduction in B cells) and decreased inflammatory cytokine levels (e.g., TNF- $\alpha$, IFN- $\gamma$, and IL-6) were consistently observed [89]. The increased presence of FoxP ${ }^{+} \mathrm{CD}^{+}$Tregs might participate 
TABle 1: Main findings of FoxP $3^{+} \mathrm{CD} 25^{+} \mathrm{CD} 4^{+}$Tregs in the pathogenesis of stroke.

\begin{tabular}{|c|c|c|c|}
\hline Species & Model & Main findings & Authors \\
\hline C57BL/6J mice & $\begin{array}{l}\text { Transient MCAO } \\
\quad(90 \text { minutes })\end{array}$ & $\begin{array}{l}\text { Splenic atrophy; an increased percentage of } \mathrm{FoxP}^{+} \mathrm{CD} 4^{+} \text {Tregs in } \\
\text { blood and spleen }\end{array}$ & $\begin{array}{l}\text { Offner et al. } \\
(2006)[89]\end{array}$ \\
\hline C57/BL6 mice & $\begin{array}{l}\text { Transient MCAO } \\
\quad(60 \text { minutes })\end{array}$ & $\begin{array}{l}\text { Accumulation of FoxP3 }{ }^{+} \text {lymphocytes in the ischemic hemisphere; a } \\
\text { high percentage of FoxP3 } 3^{+} \mathrm{CD} 4^{+} \text {and FoxP3 }{ }^{+} \mathrm{CD} 8^{+} \text {lymphocytes in } \\
\text { splenic T-lymphocytes }\end{array}$ & $\begin{array}{l}\text { Gelderblom et al. } \\
\text { (2009) [76] }\end{array}$ \\
\hline $\begin{array}{l}\text { C57BL/6 mice; } \operatorname{Ragl}^{-/-} \\
\text {mice; IL-10 knockout mice }\end{array}$ & $\begin{array}{l}\text { Transient MCAO } \\
(30 \text { minutes or } 90 \\
\text { minutes })\end{array}$ & $\begin{array}{l}\text { Neuroprotective effects of FoxP } 3^{+} \mathrm{CD} 25^{+} \mathrm{CD} 4^{+} \text {Tregs: inhibit } \\
\text { inflammatory brain damage, restrain secondary infarct expansion, } \\
\text { and attenuate functional neurological deficit; IL-10 signal pathway is } \\
\text { essential for their immunomodulatory effect }\end{array}$ & $\begin{array}{l}\text { Liesz et al. (2009) } \\
\text { [12] }\end{array}$ \\
\hline $\begin{array}{l}46 \text { consecutive acute stroke } \\
\text { patients }\end{array}$ & Clinical study & $\begin{array}{l}\text { Increased apoptosis and a decline of FoxP3 }{ }^{+} \mathrm{CD} 25^{+} \mathrm{CD} 4^{+} \text {Tregs } \\
\text { poststroke; decreased FoxP } 3^{+} \mathrm{CD} 25^{+} \mathrm{CD} 4^{+} \text {Tregs did not show a } \\
\text { correlation with the development of infection or stroke outcome }\end{array}$ & $\begin{array}{l}\text { Urra et al. (2009) } \\
\qquad[78]\end{array}$ \\
\hline $\begin{array}{l}67 \text { subjects ( } 25 \text { of them } \\
\text { with acute ischemic stroke) }\end{array}$ & Clinical study & Increased number of $\mathrm{CD} 25^{+} \mathrm{CD} 4^{+}$Tregs in the peripheral blood & $\begin{array}{l}\text { Yan et al. (2009) } \\
{[77]}\end{array}$ \\
\hline CB-17 mice; SCID mice & Permanent MCAO & $\begin{array}{l}\text { Deleption of CD25 }{ }^{+} \mathrm{T} \text { cells suppressed generation of neural } \\
\text { stem/progenitor cells and impaired functional recovery }\end{array}$ & $\begin{array}{l}\text { Saino et al. (2010) } \\
{[90]}\end{array}$ \\
\hline $\begin{array}{l}\text { C57BL/ } 6 \text { mice; } 22 \text { patients } \\
\text { with acute ischemic stroke }\end{array}$ & $\begin{array}{l}\text { Transient MCAO } \\
\text { (90 minutes); an } \\
\text { ex vivo analysis }\end{array}$ & $\begin{array}{l}\text { The suppressive effect of Tregs in the mouse and humans is unaltered } \\
\text { poststroke and reduced efficacy of circulating costimulatory cells after } \\
\text { MCAO }\end{array}$ & $\begin{array}{l}\text { Hug et al. (2011) } \\
\text { [81] }\end{array}$ \\
\hline FoxP3 ${ }^{\text {DTR }}$ mice & $\begin{array}{l}\text { Transient MCAO } \\
\quad(60 \text { minutes })\end{array}$ & FoxP ${ }^{+} \mathrm{CD}^{+}$Tregs depletion did not affect stroke infarct volume & $\begin{array}{l}\text { Ren et al. (2011) } \\
\text { [27] }\end{array}$ \\
\hline 700 subjects & Clinical study & $\begin{array}{l}\text { No correlation between low levels of circulating FoxP3 }{ }^{+} \mathrm{CD} 25^{+} \mathrm{CD} 4^{+} \\
\text {Tregs and an increased risk for the development of stroke }\end{array}$ & $\begin{array}{l}\text { Wigren et al. } \\
(2012)[82]\end{array}$ \\
\hline Sprague-Dawley rats & $\begin{array}{l}\text { Transient MCAO } \\
\text { (120 minutes) }\end{array}$ & $\begin{array}{l}\text { Adoptively transferred } \mathrm{CD} 25^{+} \mathrm{CD} 4^{+} \text {Tregs ameliorated } \\
\text { neuroinflammation, reduced brain infarct, and improved both short- } \\
\text { and long-term neurological functions after cerebral ischemia; } \\
\mathrm{CD} 25^{+} \mathrm{CD} 4^{+} \text {Tregs reduce brain infarct size via BBB protection } \\
\text { involving inhibition of neutrophil-derived MMP-9 production }\end{array}$ & $\begin{array}{l}\text { Li et al. (2013) } \\
\quad[64]\end{array}$ \\
\hline $\begin{array}{l}\text { DEREG mice; C57BL/6 } \\
\text { wild-type mice; Ragl } \\
\text { mice }\end{array}$ & $\begin{array}{l}\text { Transient MCAO } \\
\text { (30 minutes or } 60 \\
\text { minutes) }\end{array}$ & $\begin{array}{l}\text { FoxP } 3^{+} \mathrm{CD} 25^{+} \mathrm{CD}^{+} \text {Tregs strongly promoted acute ischemic stroke in } \\
\text { mice by inducing dysfunction of the cerebral microvasculature; } \\
\text { established immunoregulatory effects of FoxP } 3^{+} \mathrm{CD} 4^{+} \text {Tregs had no } \\
\text { functional relevance }\end{array}$ & $\begin{array}{l}\text { Kleinschnitz et al. } \\
\text { (2013) [28] }\end{array}$ \\
\hline $\begin{array}{l}\text { FoxP3 } 3^{\text {EGFP }} \text { reporter mice; } \\
\mathrm{RAG}^{-/-} \text {mice; } \mathrm{C} 57 \mathrm{BL} / 6 \mathrm{~J} \\
\text { mice }\end{array}$ & $\begin{array}{l}\text { Transient MCAO } \\
\text { (30 minutes) }\end{array}$ & $\begin{array}{l}\text { A strong accumulation and proliferation of FoxP3 } 3^{+} \mathrm{CD} 25^{+} \mathrm{CD} 4^{+} \text {Tregs } \\
\text { in the ischemic hemisphere in late phase (peaked around days } 14 \text { and } \\
\text { up to days 30); delayed depletion of } \mathrm{CD} 25^{+} \text {Tregs does not worsen } \\
\text { long-term outcome }\end{array}$ & $\begin{array}{l}\text { Stubbe et al. } \\
(2013)[80]\end{array}$ \\
\hline
\end{tabular}

MCAO: middle cerebral artery occlusion; MMP-9: Matrix metallopeptidase 9; BBB: blood-brain barrier; Tregs: regulatory T-cells.

in stroke-induced immunosuppression on the peripheral immune system [89]. FoxP3 ${ }^{+} \mathrm{CD}^{+}$Tregs appear to exert an unfavorable role as immunosuppressive modulators and increase infection susceptibility following stroke. Liesz et al., however, reported that FoxP $3{ }^{+} \mathrm{CD} 25^{+} \mathrm{CD} 4{ }^{+}$Tregs restrained secondary infarct expansion and attenuated functional neurological deficits after stroke [12]. FoxP $3^{+} \mathrm{CD} 25^{+} \mathrm{CD} 4^{+}$Tregs inhibited excessive local and systemic production of proinflammatory cytokines (e.g., IL- $1 \beta$, IFN- $\gamma$ ) and reduced invasion and/or activation of neutrophils, lymphocytes, and activated microglia after acute focal brain ischemia via activating the cerebroprotective IL-10 signaling pathway [12]. Furthermore, depletion of $\mathrm{CD} 25^{+} \mathrm{T}$ cells, a cell population including Tregs, suppresses the generation of neural stem cells and progenitor cells as well as impairs functional recovery in CB-17 mice after ischemic injury, suggesting Tregs have possible beneficial effects by promoting neurogenesis
[90]. The specificity of CD25 antibody-mediated depletion of Tregs, however, is very questionable. Furthermore, it has been reported that FoxP3 ${ }^{+} \mathrm{CD} 25^{+} \mathrm{CD} 4^{+}$Tregs may be a facilitator for Cocaine-and-amphetamine-regulated-transcript(CART-) mediated neuroprotection after stroke [91]. In an MCAO model, $710 \mathrm{~nm}$ wavelength visible light irradiation reduced brain infarction and enhanced functional recovery, perhaps by altering cellular immunity, including increasing the number of $\mathrm{CD} 25^{+} \mathrm{CD} 4^{+}$Tregs and decreasing microglia activation in the ischemic core and the peri-infarct region [92]. Moreover, intravenous albumin administration reduced Toll-like receptor 4 expression but significantly increased FoxP $3^{+} \mathrm{CD} 25^{+} \mathrm{CD} 4^{+}$Tregs expression levels and elevated IL10 and TGF- $\beta 1$ production, eventually conferring neuroprotective effects during postischemic stroke treatment [93].

While FoxP3 ${ }^{+} \mathrm{CD} 25^{+} \mathrm{CD} 4^{+}$Tregs have beneficial effects after stroke, we should not ignore their possible detrimental 
effects. Recently, several findings do not support the neuroprotective effects of $\mathrm{FoxP}^{+} \mathrm{CD} 25^{+} \mathrm{CD} 4^{+}$Tregs in stroke treatment. One study demonstrated that depletion of FoxP $3^{+} \mathrm{CD}^{+}$Tregs by utilizing diphtheria toxin prior to stroke induction failed to reduce infarct volume at 96 hours after MCAO and reperfusion injury [27]. Moreover, another study declared that $\mathrm{FoxP}^{+} \mathrm{CD}^{+}{ }^{+}$Tregs greatly augmented acute ischemic/reperfusion injury after stroke, and this detrimental effect persisted into the later period of infarct development in a DEREG mouse model [28]. Adoptive transfer of $\mathrm{FoxP}_{3}^{+} \mathrm{CD} 25^{+} \mathrm{CD} 4^{+}$Tregs and $\mathrm{CD} 25^{+} \mathrm{CD} 4^{+}$ Tregs into C57BL/6 wild-type mice and $\mathrm{Ragl}^{-/-}$mice verified the observed injurious results [28]. The harmful effects from FoxP3 ${ }^{+} \mathrm{CD} 4^{+}$Tregs in the present study were attributed to FoxP3 ${ }^{+} \mathrm{CD}^{+}$Treg-induced cerebral microvascular dysfunction and thrombosis, as evaluated by 17.6 Tesla ultrahigh-field magnetic resonance imaging [28]. In contrast, established immunoregulatory effects of FoxP $3^{+} \mathrm{CD}^{+}$Tregs had no functional relevance in this model [28]. FoxP3 $3^{+} \mathrm{CD} 4^{+}$Treg could possibly be prone to adhering to the vascular endothelium via LFA-1/ICAM-1 binding under ischemic conditions [28]. Furthermore, inconsistent with the previous findings discussed above [90], one study showed that CD25 antibodymediated depletion of $\mathrm{CD} 25^{+}$Tregs failed to affect long-term outcomes after MCAO, suggesting the differential participation of specific immune cell types under distinct experimental schemes [80]. The specificity of CD25 antibody-mediated depletion of Tregs should be taken into consideration.

In conclusion, both beneficial and detrimental effects of FoxP $3^{+} \mathrm{CD} 25^{+} \mathrm{CD} 4^{+}$Tregs in stroke have been currently referenced. It is imperative to advance our understanding and authenticate the roles of FoxP $3^{+} \mathrm{CD} 25^{+} \mathrm{CD} 4^{+}$Tregs and their underlying mechanisms in stroke pathophysiology.

\section{Future Direction}

From the summary above, we proposed possible important functions of FoxP $3^{+} \mathrm{CD} 25^{+} \mathrm{CD} 4^{+}$Tregs in poststroke immunological events. Considering the absence of other specific strategies or drugs for patients with stroke, modulating the quantity and function of FoxP $3^{+} \mathrm{CD} 25^{+} \mathrm{CD} 4^{+}$Tregs may be potential, novel avenues for developing new therapeutics that improve neurological outcomes after stroke. For instance, we may increase the number of FoxP $3^{+} \mathrm{CD} 25^{+} \mathrm{CD} 4^{+}$ Tregs in the poststroke brain by adoptive transfer via intravenous injection, stimulation by pharmacological compounds, such as retinal and albumin, and genetic engineering techniques [32, 64, 93-95]. Since appropriate Treg migration and retention are required for Treg-mediated immune suppression, which can be modulated [96], we also hypothesize that increase of $\mathrm{FoxP}^{+} \mathrm{CD} 25^{+} \mathrm{CD} 4^{+}$Treg mobilization into CNS would be beneficial. Nevertheless, a series of critical issues associated with $\mathrm{FoxP}^{+} \mathrm{CD} 25^{+} \mathrm{CD} 4^{+}$ Tregs remain to be resolved. First and foremost, the complex interaction between the brain and immune system during stroke pathogenesis is not fully understood and requires further elucidation. Secondly, the fundamental questions regarding $\mathrm{FoxP}^{+} \mathrm{CD}_{25} \mathrm{CD}^{+}{ }^{+}$Tregs, such as their temporal and spatial dynamics, significance, and underlying immunomodulatory mechanisms in stroke, need to be answered. Importantly, $\mathrm{FoxP}^{+} \mathrm{CD} 25^{+} \mathrm{CD} 4^{+}$Treg-mediated immunosuppression could be protective or harmful at different stages of stroke [12, 73, 74]. Therefore, the principle issue behind a therapeutic intervention based on FoxP3 ${ }^{+} \mathrm{CD} 25^{+} \mathrm{CD} 4^{+}$Treg modulation is identifying the precise roles of $\mathrm{FoxP}^{+} \mathrm{CD} 25^{+} \mathrm{CD} 4^{+}$Tregs at specific stages of stroke. Thirdly, future experiments should determine how FoxP $3^{+} \mathrm{CD} 25^{+} \mathrm{CD} 4^{+}$Tregs infiltrate the brain and explore the role of Treg migratory markers. Given ROS are key mediators in stroke pathology, it is important to take into account the potential endogenous antioxidative properties Tregs may possess, which merit more investigation. Furthermore, since current Treg research mainly concentrated on ischemic rather than hemorrhagic stroke, future studies should broaden their knowledge of FoxP $3^{+} \mathrm{CD} 25^{+} \mathrm{CD} 4^{+}$ Tregs in hemorrhagic stroke, including subarachnoid hemorrhage, intracerebral hemorrhage, and hemorrhagic transformation. Moreover, because evidence acquired from animal experiments is often difficult to transfer into clinical study [97], more attention should be paid to the translational value between basic research and clinical trials in the investigation of FoxP $3^{+} \mathrm{CD}_{2} 5^{+} \mathrm{CD} 4^{+}$Tregs following stroke. Finally, in view of the current technical difficulties in defining human $\mathrm{FoxP}^{+}{ }^{+} \mathrm{CD} 25^{+} \mathrm{CD} 4^{+}$Tregs [82], we suggest more efforts should be undertaken to develop novel, specific detection means for FoxP $3^{+} \mathrm{CD} 25^{+} \mathrm{CD} 4^{+}$Tregs.

\section{Conclusion}

Some evidence depicts the unique role of $\mathrm{FoxP}^{+} \mathrm{CD} 25^{+} \mathrm{CD} 4^{+}$Tregs in stroke pathogenesis. Whether FoxP3 ${ }^{+} \mathrm{CD} 25^{+} \mathrm{CD} 4^{+}$Tregs are friends or foes in stroke, however, remains unclear. Therefore, future investigations should focus on the reliable definition as well as the further determination of the real roles and underlying mechanisms of FoxP $3^{+} \mathrm{CD} 25^{+} \mathrm{CD} 4^{+}$Treg-mediated immune regulation following stroke. Advancing our understanding of FoxP $3^{+} \mathrm{CD} 25^{+} \mathrm{CD} 4^{+}$Tregs and utilizing FoxP $3^{+} \mathrm{CD} 25^{+} \mathrm{CD} 4^{+}$ Tregs to selectively suppress the deleterious effects of excessive brain immunoreaction after stroke may provide novel therapeutic approaches for stroke patients.

\section{Conflict of Interests}

The authors have no conflict of interests.

\section{Acknowledgments}

Dr. J Tang is supported by grants from NIH (NS060936). Dr. Y. Hong is supported by grants from Research Fund for the Doctoral Program of Higher Education of China (20120101120030), Zhejiang Provincial Natural Science Foundation of China (LY13H090002), and Health Bureau of Zhejiang Province (2013KYA088).

\section{References}

[1] C. J. Workman, A. L. Szymczak-Workman, L. W. Collison, M. R. Pillai, and D. A. A. Vignali, "The development and function 
of regulatory T cells," Cellular and Molecular Life Sciences, vol. 66, no. 16, pp. 2603-2622, 2009.

[2] Q. Tang and J. A. Bluestone, "The Foxp $3^{+}$regulatory T cell: a jack of all trades, master of regulation," Nature Immunology, vol. 9, no. 3, pp. 239-244, 2008.

[3] H. Offner and P. D. Hurn, "A novel hypothesis: regulatory B lymphocytes shape outcome from experimental stroke," Translational Stroke Research, vol. 3, no. 3, pp. 324-330, 2012.

[4] W. Maes, T. Verschuere, A. Van Hoylandt, L. Boon, and S. Van Gool, "Depletion of regulatory T cells in a mouse experimental glioma model through anti-CD25 treatment results in the infiltration of non-immunosuppressive myeloid cells in the brain," Clinical and Developmental Immunology, vol. 2013, Article ID 952469, 6 pages, 2013.

[5] S. Sakaguchi, M. Ono, R. Setoguchi et al., "FoxP3 ${ }^{+} \mathrm{CD} 25^{+} \mathrm{CD} 4^{+}$ natural regulatory $\mathrm{T}$ cells in dominant self-tolerance and autoimmune disease," Immunological Reviews, vol. 212, pp. 8-27, 2006.

[6] S. Sakaguchi, "Naturally arising $\mathrm{CD}^{+}$regulatory $\mathrm{T}$ cells for immunologic self-tolerance and negative control of immune responses," Annual Review of Immunology, vol. 22, pp. 531-562, 2004.

[7] W. M. T. Braga, D. Atanackovic, and G. W. B. Colleoni, "The role of regulatory T cells and TH17 cells in multiple myeloma," Clinical and Developmental Immunology, vol. 2012, Article ID 293479, 4 pages, 2012.

[8] M. F. Cusick, J. J. Schiller, J. C. Gill, and D. D. Eckels, "Hepatitis $\mathrm{C}$ virus induces regulatory $\mathrm{T}$ cells by naturally occurring viral variants to suppress T cell responses," Clinical and Developmental Immunology, vol. 2011, Article ID 806061, 15 pages, 2011.

[9] J. T. Walsh and J. Kipnis, "Regulatory T cells in CNS injury: the simple, the complex and the confused," Trends in Molecular Medicine, vol. 17, no. 10, pp. 541-547, 2011.

[10] F. He and R. Balling, "The role of regulatory T cells in neurodegenerative diseases," Wiley Interdisciplinary Reviews-Systems Biology and Medicine, vol. 5, no. 2, pp. 153-180, 2013.

[11] A. L. Zozulya and H. Wiendl, "The role of regulatory T cells in multiple sclerosis," Nature Clinical Practice Neurology, vol. 4, no. 7, pp. 384-398, 2008.

[12] A. Liesz, E. Suri-Payer, C. Veltkamp et al., "Regulatory T cells are key cerebroprotective immunomodulators in acute experimental stroke," Nature Medicine, vol. 15, no. 2, pp. 192-199, 2009.

[13] D. E. Lowther and D. A. Hafler, "Regulatory T cells in the central nervous system," Immunological Reviews, vol. 248, no. 1, pp. 156169, 2012.

[14] B. Norrving and B. Kissela, "The global burden of stroke and need for a continuum of care," Neurology, vol. 80, no. 3, supplement 2, pp. S5-S12, 2013.

[15] N. Tajiri, T. Dailey, C. Metcalf et al., "In vivo animal stroke models: a rationale for rodent and non-human primate models," Translational Stroke Research, vol. 4, no. 3, pp. 308-321, 2013.

[16] G. J. Del Zoppo, J. L. Saver, E. C. Jauch, and H. P. Adams, "Expansion of the time window for treatment of acute ischemic stroke with intravenous tissue plasminogen activator: a science advisory from the American heart association/american stroke association," Stroke, vol. 40, no. 8, pp. 2945-2948, 2009.

[17] T. M. Woodruff, J. Thundyil, S.-C. Tang, C. G. Sobey, S. M. Taylor, and T. V. Arumugam, "Pathophysiology, treatment, and animal and cellular models of human ischemic stroke," Molecular Neurodegeneration, vol. 6, no. 1, article 11, 2011.
[18] C. Iadecola and J. Anrather, "The immunology of stroke: from mechanisms to translation," Nature Medicine, vol. 17, no. 7, pp. 796-808, 2011.

[19] M. D. Hammond, Y. Ai, and L. H. Sansing, "Grl+ macrophages and dendritic cells dominate the inflammatory infiltrate 12 $\mathrm{h}$ after experimental intracerebral hemorrhage," Translational Stroke Research, vol. 3, no. 1, pp. s125-s131, 2012.

[20] P. A. Mccombe and S. J. Read, "Immune and inflammatory responses to stroke: good or bad?" International Journal of Stroke, vol. 3, no. 4, pp. 254-265, 2008.

[21] H. Offner, S. Subramanian, S. M. Parker, M. E. Afentoulis, A. A. Vandenbark, and P. D. Hurn, "Experimental stroke induces massive, rapid activation of the peripheral immune system," Journal of Cerebral Blood Flow and Metabolism, vol. 26, no. 5, pp. 654-665, 2006.

[22] H. C. A. Emsley and S. J. Hopkins, "Post-stroke immunodepression and infection: an emerging concept," Infectious Disorders, vol. 10, no. 2, pp. 91-97, 2010.

[23] N. Fathali, R. P. Ostrowski, Y. Hasegawa et al., "Splenic immune cells in experimental neonatal hypoxia-ischemia," Translational Stroke Research, vol. 4, no. 2, pp. 208-219, 2013.

[24] R. Macrez, C. Ali, O. Toutirais et al., "Stroke and the immune system: from pathophysiology to new therapeutic strategies," The Lancet Neurology, vol. 10, no. 5, pp. 471-480, 2011.

[25] S. W. Yoo, D. Y. Chang, H. S. Lee et al., "Immune following suppression mesenchymal stem cell transplantation in the ischemic brain is mediated by TGF-beta," Neurobiology of Disease, vol. 58C, pp. 249-257, 2013.

[26] L. Li, A. Lundkvist, D. Andersson et al., "Protective role of reactive astrocytes in brain ischemia," Journal of Cerebral Blood Flow and Metabolism, vol. 28, no. 3, pp. 468-481, 2008.

[27] X. Ren, K. Akiyoshi, A. A. Vandenbark, P. D. Hurn, and H. Offner, "CD4 ${ }^{+} \mathrm{Foxp}^{+}$regulatory T-cells in cerebral ischemic stroke," Metabolic Brain Disease, vol. 26, no. 1, pp. 87-90, 2011.

[28] C. Kleinschnitz, P. Kraft, A. Dreykluft et al., "Regulatory T cells are strong promoters of acute ischemic stroke in mice by inducing dysfunction of the cerebral microvasculature," Blood, vol. 121, no. 4, pp. 679-691, 2013.

[29] M. A. Jenabian, P. Ancuta, N. Gilmore, and J. P. Routy, "Regulatory T cells in HIV infection: can immunotherapy regulate the regulator?" Clinical and Developmental Immunology, vol. 2012, Article ID 908314, 12 pages, 2012.

[30] E. M. Shevach, "Mechanisms of Foxp $3^{+}$T regulatory cell-mediated suppression," Immunity, vol. 30, no. 5, pp. 636-645, 2009.

[31] A. Corthay, "How do regulatory t cells work?" Scandinavian Journal of Immunology, vol. 70, no. 4, pp. 326-336, 2009.

[32] K. G. Schmetterer, A. Neunkirchner, and W. F. Pickl, "Naturally occurring regulatory T cells: markers, mechanisms, and manipulation," The FASEB Journal, vol. 26, no. 6, pp. 2253-2276, 2012.

[33] S. Sakaguchi, N. Sakaguchi, M. Asano, M. Itoh, and M. Toda, "Immunologic self-tolerance maintained by activated $\mathrm{T}$ cells expressing IL-2 receptor $\alpha$-chains (CD25): breakdown of a single mechanism of self-tolerance causes various autoimmune diseases," Journal of Immunology, vol. 155, no. 3, pp. 1151-1164, 1995.

[34] N. Nik Tavakoli, B. D. Hambly, D. R. Sullivan, and S. Bao, "Forkhead box protein 3: essential immune regulatory role," International Journal of Biochemistry and Cell Biology, vol. 40, no. 11, pp. 2369-2373, 2008.

[35] S. Sakaguchi, "Naturally arising Foxp3-expressing CD $25^{+} \mathrm{CD} 4^{+}$ regulatory $\mathrm{T}$ cells in immunological tolerance to self and nonself," Nature Immunology, vol. 6, no. 4, pp. 345-352, 2005. 
[36] R. Setoguchi, S. Hori, T. Takahashi, and S. Sakaguchi, "Homeostatic maintenance of natural Foxp $3^{+} \mathrm{CD} 25^{+} \mathrm{CD} 4^{+}$regulatory T cells by interleukin (IL)- 2 and induction of autoimmune disease by IL-2 neutralization," Journal of Experimental Medicine, vol. 201, no. 5, pp. 723-735, 2005.

[37] B. Jin, T. Sun, X. H. Yu, Y. X. Yang, and A. E. Yeo, "The effects of TLR activation on T-cell development and differentiation," Clinical and Developmental Immunology, vol. 2012, Article ID 836485, 32 pages, 2012.

[38] S. E. Allan, R. Broady, S. Gregori et al., "CD4+ T-regulatory cells: toward therapy for human diseases," Immunological Reviews, vol. 223, no. 1, pp. 391-421, 2008.

[39] B. Li, A. Samanta, X. Song et al., "FOXP3 ensembles in T-cell regulation," Immunological Reviews, vol. 212, pp. 99-113, 2006.

[40] U. Oh, C. Grant, C. Griffith, K. Fugo, N. Takenouchi, and S. Jacobson, "Reduced Foxp3 protein expression is associated with inflammatory disease during human T lymphotropic virus type 1 infection," Journal of Infectious Diseases, vol. 193, no. 11, pp. 1557-1566, 2006.

[41] E. Gambineri, T. R. Torgerson, and H. D. Ochs, "Immune dysregulation, polyendocrinopathy, enteropathy, and X-linked inheritance (IPEX), a syndrome of systemic autoimmunity caused by mutations of FOXP3, a critical regulator of T-cell homeostasis," Current Opinion in Rheumatology, vol. 15, no. 4, pp. 430-435, 2003.

[42] E. Bettelli, M. Dastrange, and M. Oukka, "Foxp3 interacts with nuclear factor of activated T cells and NF- $\kappa \mathrm{B}$ to repress cytokine gene expression and effector functions of T helper cells," Proceedings of the National Academy of Sciences of the United States of America, vol. 102, no. 14, pp. 5138-5143, 2005.

[43] L. A. Schubert, E. Jeffery, Y. Zhang, F. Ramsdell, and S. F. Ziegler, "Scurfin (FOXP3) acts as a repressor of transcription and regulates T cell activation," Journal of Biological Chemistry, vol. 276, no. 40, pp. 37672-37679, 2001.

[44] C. Grant, U. Oh, K. Fugo et al., "Foxp3 represses retroviral transcription by targeting both NF-kappaB and CREB pathways," PLoS Pathogens, vol. 2, no. 4, p. e33, 2006.

[45] J. Villaseñor, C. Benoist, and D. Mathis, "AIRE and APECED: molecular insights into an autoimmune disease," Immunological Reviews, vol. 204, pp. 156-164, 2005.

[46] S. F. Ziegler, "FOXP3: of mice and men," Annual Review of Immunology, vol. 24, pp. 209-226, 2006.

[47] K. J. Scalapino and D. I. Daikh, "CTLA-4: a key regulatory point in the control of autoimmune disease," Immunological Reviews, vol. 223, no. 1, pp. 143-155, 2008.

[48] M. Razmara, B. Hilliard, A. K. Ziarani, Y. H. Chen, and M. L. Tykocinski, "CTLA-4-Ig converts naive $\mathrm{CD} 4{ }^{+} \mathrm{CD} 25^{-} \mathrm{T}$ cells into $\mathrm{CD} 4^{+} \mathrm{CD} 25^{+}$regulatory T cells," International Immunology, vol. 20, no. 4, pp. 471-483, 2008.

[49] D. M. Sansom and L. S. K. Walker, "The role of CD28 and cytotoxic T-lymphocyte antigen-4 (CTLA-4) in regulatory T-cell biology," Immunological Reviews, vol. 212, pp. 131-148, 2006.

[50] B. Birebent, R. Lorho, H. Lechartier et al., "Suppressive properties of human $\mathrm{CD} 4{ }^{+} \mathrm{CD} 25^{+}$regulatory T cells are dependent on CTLA-4 expression," European Journal of Immunology, vol. 34, no. 12, pp. 3485-3496, 2004.

[51] P. Kolar, K. Knieke, J. K. E. Hegel et al., “CTLA-4 (CD152) controls homeostasis and suppressive capacity of regulatory $\mathrm{T}$ cells in mice," Arthritis and Rheumatism, vol. 60, no. 1, pp. 123-132, 2009.
[52] K. Loser and S. Beissert, "Regulatory T cells: banned cells for decades," Journal of Investigative Dermatology, vol. 132, no. 3, part 2, pp. 864-871, 2012.

[53] K. Wing, Y. Onishi, P. Prieto-Martin et al., "CTLA-4 control over Foxp $3^{+}$regulatory T cell function," Science, vol. 322, no. 5899, pp. 271-275, 2008.

[54] T. Takahashi, T. Tagami, S. Yamazaki et al., "Immunologic selftolerance maintained by $\mathrm{CD} 25^{+} \mathrm{CD} 4^{+}$regulatory T cells constitutively expressing cytotoxic $\mathrm{T}$ lymphocyte-associated antigen 4," Journal of Experimental Medicine, vol. 192, no. 2, pp. 303$309,2000$.

[55] H. Kataoka, S. Takahashi, K. Takase et al., "CD25 ${ }^{+} \mathrm{CD} 4^{+}$regulatory $\mathrm{T}$ cells exert in vitro suppressive activity independent of CTLA-4," International Immunology, vol. 17, no. 4, pp. 421-427, 2005.

[56] L. Gorelik and R. A. Flavell, "Transforming growth factor- $\beta$ in T-cell biology," Nature Reviews Immunology, vol. 2, no. 1, pp. 46$53,2002$.

[57] L. Zhang, H. Yi, X.-P. Xia, and Y. Zhao, “Transforming growth factor-beta: an important role in $\mathrm{CD} 4{ }^{+} \mathrm{CD} 25^{+}$regulatory T cells and immune tolerance," Autoimmunity, vol. 39, no. 4, pp. 269276, 2006.

[58] M. C. Fantini, C. Becker, G. Monteleone, F. Pallone, P. R. Galle, and M. F. Neurath, "Cutting edge: TGF-beta induces a regulatory phenotype in $\mathrm{CD} 4^{+} \mathrm{CD} 25^{-} \mathrm{T}$ cells through Foxp3 induction and down-regulation of Smad7,' Journal of Immunology, vol. 172, no. 9, pp. 5149-5153, 2004.

[59] J. C. Marie, J. J. Letterio, M. Gavin, and A. Y. Rudensky, “TGF$\beta 1$ maintains suppressor function and Foxp3 expression in $\mathrm{CD} 4{ }^{+} \mathrm{CD} 25^{+}$regulatory T cells," Journal of Experimental Medicine, vol. 201, no. 7, pp. 1061-1067, 2005.

[60] Y. Shi, M. Fukuoka, G. Li et al., "Regulatory T cells protect mice against coxsackievirus-induced myocarditis through the transforming growth factor $\beta$-coxsackie-adenovirus receptor pathway," Circulation, vol. 121, no. 24, pp. 2624-2634, 2010.

[61] M. Grilli, I. Barbieri, H. Basudev et al., "Interleukin-10 modulates neuronal threshold of vulnerability to ischaemic damage," European Journal of Neuroscience, vol. 12, no. 7, pp. 2265-2272, 2000.

[62] P. A. Spera, J. A. Ellison, G. Z. Feuerstein, and F. C. Barone, "IL10 reduces rat brain injury following focal stroke," Neuroscience Letters, vol. 251, no. 3, pp. 189-192, 1998.

[63] W. Ouyang, S. Rutz, N. K. Crellin, P. A. Valdez, and S. G. Hymowitz, "Regulation and functions of the IL-10 family of cytokines in inflammation and disease," Annual Review of Immunology, vol. 29, pp. 71-109, 2011.

[64] P. Li, Y. Gan, B. L. Sun et al., "Adoptive regulatory T-cell therapy protects against cerebral ischemia," Annals of Neurology, 2013.

[65] A. M. Thornton and E. M. Shevach, "Suppressor effector function of $\mathrm{CD} 4{ }^{+} \mathrm{CD} 25^{+}$immunoregulatory T cells is antigen nonspecific," Journal of Immunology, vol. 164, no. 1, pp. 183-190, 2000.

[66] F. Jadidi-Niaragh and A. Mirshafiey, "Regulatory T-cell as orchestra leader in immunosuppression process of multiple sclerosis," Immunopharmacology and Immunotoxicology, vol. 33, no. 3, pp. 545-567, 2011.

[67] A. M. C. Faria and H. L. Weiner, "Oral tolerance: therapeutic implications for autoimmune diseases," Clinical and Developmental Immunology, vol. 13, no. 2-4, pp. 143-157, 2006.

[68] V. Viglietta, C. Baecher-Allan, H. L. Weiner, and D. A. Hafler, "Loss of functional suppression by $\mathrm{CD} 4{ }^{+} \mathrm{CD} 25^{+}$regulatory $\mathrm{T}$ 
cells in patients with multiple sclerosis," Journal of Experimental Medicine, vol. 199, no. 7, pp. 971-979, 2004.

[69] A. P. Kohm, P. A. Carpentier, H. A. Anger, and S. D. Miller, "Cutting edge: $\mathrm{CD} 4{ }^{+} \mathrm{CD} 25^{+}$regulatory T cells suppress antigenspecific autoreactive immune responses and central nervous system inflammation during active experimental autoimmune encephalomyelitis," Journal of Immunology, vol. 169, no. 9, pp. 4712-4716, 2002.

[70] A. D. Reynolds, R. Banerjee, J. Liu, H. E. Gendelman, and R. L. Mosley, "Neuroprotective activities of $\mathrm{CD} 4{ }^{+} \mathrm{CD} 25^{+}$regulatory T cells in an animal model of Parkinson's disease," Journal of Leukocyte Biology, vol. 82, no. 5, pp. 1083-1094, 2007.

[71] A. D. Reynolds, D. K. Stone, R. L. Mosley, and H. E. Gendelman, "Proteomic studies of nitrated alpha-synuclein microglia regulation by $\mathrm{CD} 4{ }^{+} \mathrm{CD} 25^{+} \mathrm{T}$ cells," Journal of Proteome Research, vol. 8, no. 7, pp. 3497-3511, 2009.

[72] G. Moalem, R. Leibowitz-Amit, E. Yoles, F. Mor, I. R. Cohen, and M. Schwartz, "Autoimmune T cells protect neurons from secondary degeneration after central nervous system axotomy," Nature Medicine, vol. 5, no. 1, pp. 49-55, 1999.

[73] J. Kipnis, H. Avidan, R. R. Caspi, and M. Schwartz, "Dual effect of $\mathrm{CD} 4{ }^{+} \mathrm{CD} 25^{+}$regulatory T cells in neurodegeneration: a dialogue with microglia," Proceedings of the National Academy of Sciences of the United States of America, vol. 101, no. 2, pp. 14663-14669, 2004.

[74] J. Kipnis, T. Mizrahi, E. Hauben, I. Shaked, E. Shevach, and M. Schwartz, "Neuroprotective autoimmunity: naturally occurring $\mathrm{CD} 4{ }^{+} \mathrm{CD} 25^{+}$regulatory $\mathrm{T}$ cells suppress the ability to withstand injury to the central nervous system," Proceedings of the National Academy of Sciences of the United States of America, vol. 99, no. 24, pp. 15620-15625, 2002.

[75] J. Liu, N. Gong, X. Huang, A. D. Reynolds, R. L. Mosley, and H. E. Gendelman, "Neuromodulatory activities of $\mathrm{CD} 4^{+} \mathrm{CD} 25^{+}$ regulatory T cells in a murine model of HIV-1-associated neurodegeneration," Journal of Immunology, vol. 182, no. 6, pp. 38553865, 2009.

[76] M. Gelderblom, F. Leypoldt, K. Steinbach et al., "Temporal and spatial dynamics of cerebral immune cell accumulation in stroke," Stroke, vol. 40, no. 5, pp. 1849-1857, 2009.

[77] J. Yan, J. M. Greer, K. Etherington et al., "Immune activation in the peripheral blood of patients with acute ischemic stroke," Journal of Neuroimmunology, vol. 206, no. 1-2, pp. 112-117, 2009.

[78] X. Urra, Á. Cervera, N. Villamor, A. M. Planas, and Á. Chamorro, "Harms and benefits of lymphocyte subpopulations in patients with acute stroke," Neuroscience, vol. 158, no. 3, pp. 1174-1183, 2009.

[79] J. Yan, S. J. Read, R. D. Henderson et al., "Frequency and function of regulatory T cells after ischaemic stroke in humans," Journal of Neuroimmunology, vol. 243, no. 1-2, pp. 89-94, 2012.

[80] T. Stubbe, F. Ebner, D. Richter et al., "Regulatory T cells accumulate and proliferate in the ischemic hemisphere for up to 30 days after MCAO," Journal of Cerebral Blood Flow \& Metabolism, vol. 33, no. 1, pp. 37-47, 2013.

[81] A. Hug, A. Liesz, B. Muerle et al., "Reduced efficacy of circulating costimulatory cells after focal cerebral ischemia," Stroke, vol. 42, no. 12, pp. 3580-3586, 2011.

[82] M. Wigren, H. Bjorkbacka, L. Andersson et al., "Low levels of circulating $\mathrm{CD}^{+} \mathrm{FoxP}^{+} \mathrm{T}$ cells are associated with an increased risk for development of myocardial infarction but not for stroke," Arteriosclerosis Thrombosis and Vascular Biology, vol. 32, no. 8, pp. 2000-2007, 2012.
[83] Y. Chen, V. K. Kuchroo, J.-I. Inobe, D. A. Hafler, and H. L. Weiner, "Regulatory $\mathrm{T}$ cell clones induced by oral tolerance: suppression of autoimmune encephalomyelitis," Science, vol. 265, no. 5176, pp. 1237-1240, 1994.

[84] H. Groux, A. O’Garra, M. Bigler et al., "A CD4 ${ }^{+}$T-cell subset inhibits antigen-specific T-cell responses and prevents colitis," Nature, vol. 389, no. 6652, pp. 737-742, 1997.

[85] Y. Chen, C. Ruetzler, S. Pandipati et al., "Mucosal tolerance to E-selectin provides cell-mediated protection against ischemic brain injury," Proceedings of the National Academy of Sciences of the United States of America, vol. 100, no. 25, pp. 15107-15112, 2003.

[86] J. M. Gee, A. Kalil, M. Thullbery, and K. J. Becker, "Induction of immunologic tolerance to myelin basic protein prevents central nervous system autoimmunity and improves outcome after stroke," Stroke, vol. 39, no. 5, pp. 1575-1582, 2008.

[87] J. M. Gee, D. Zierath, J. Hadwin et al., "Long term immunologic consequences of experimental stroke and mucosal tolerance," Experimental \& Translational Stroke Medicine, vol. 1, p. 3, 2009.

[88] S. Ishibashi, D. Maric, Y. Mou, R. Ohtani, C. Ruetzler, and J. M. Hallenbeck, "Mucosal tolerance to E-selectin promotes the survival of newly generated neuroblasts via regulatory T-cell induction after stroke in spontaneously hypertensive rats," Journal of Cerebral Blood Flow and Metabolism, vol. 29, no. 3, pp. 606-620, 2009.

[89] H. Offner, S. Subramanian, S. M. Parker et al., "Splenic atrophy in experimental stroke is accompanied by increased regulatory $\mathrm{T}$ cells and circulating macrophages," Journal of Immunology, vol. 176, no. 11, pp. 6523-6531, 2006.

[90] O. Saino, A. Taguchi, T. Nakagomi et al., "Immunodeficiency reduces neural stem/progenitor cell apoptosis and enhances neurogenesis in the cerebral cortex after stroke," Journal of Neuroscience Research, vol. 88, no. 11, pp. 2385-2397, 2010.

[91] L. Chang, Y. Chen, J. Li et al., "Cocaine-and amphetamineregulated transcript modulates peripheral immunity and protects against brain injury in experimental stroke," Brain, Behavior, and Immunity, vol. 25, no. 2, pp. 260-269, 2011.

[92] D.-H. Choi, J. H. Lim, K.-H. Lee et al., "Effect of $710 \mathrm{~nm}$ visible light irradiation on neuroprotection and immune function after stroke," NeuroImmunoModulation, vol. 19, no. 5, pp. 267-276, 2012.

[93] M. Wang, Y. Wang, J. He et al., "Albumin induces neuroprotection against ischemic stroke by altering Toll-like receptor 4 and regulatory T cells in mice," CNS \& Neurological Disorders, vol. 12, no. 2, pp. 220-227, 2013.

[94] T. Yamaguchi, A. Kishi, M. Osaki et al., "Construction of selfrecognizing regulatory $\mathrm{T}$ cells from conventional $\mathrm{T}$ cells by controlling CTLA-4 and IL-2 expression," Proceedings of the National Academy of Sciences of the United States of America, vol. 110, no. 23, pp. E2116-E2125, 2013.

[95] M. K. Park, J. Y. Jhun, S. Y. Lee et al., "Retinal attenuates inflammatory arthritis by reciprocal regulation of IL-17-producing $\mathrm{T}$ cells and Foxp $3^{+}$regulatory T cells and the inhibition of osteoclastogenesis," Immunology Letters, vol. 148, no. 1, pp. 59-68, 2012.

[96] S. Wei, I. Kryczek, and W. Zou, "Regulatory T-cell compartmentalization and trafficking," Blood, vol. 108, no. 2, pp. 426-431, 2006.

[97] P. A. Lapchak, J. H. Zhang, and L. J. Noble-Haeusslein, "RIGOR guidelines: escalating STAIR and STEPS for effective translational research," Translational Stroke Research, vol. 4, no. 3, pp. 279-285, 2013. 


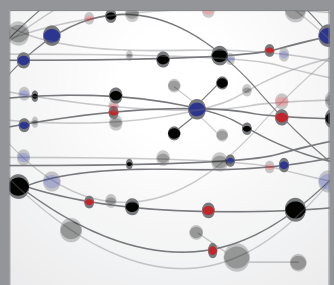

The Scientific World Journal
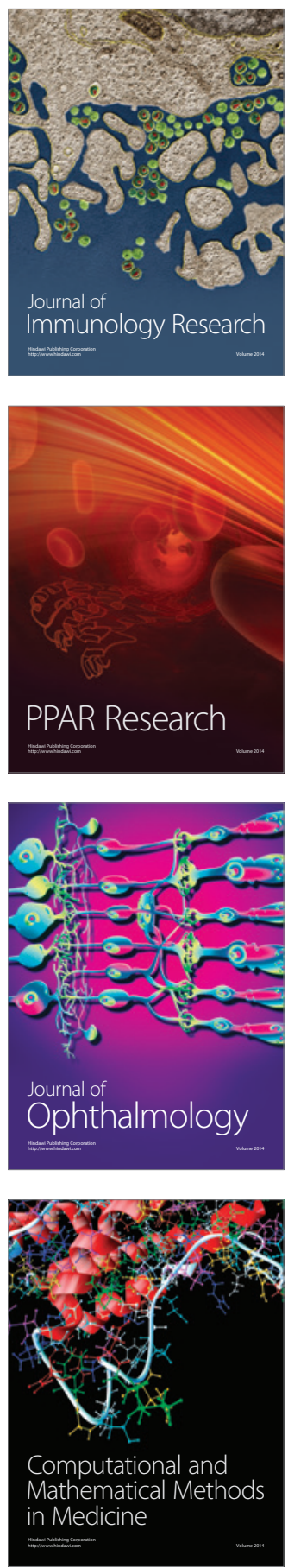

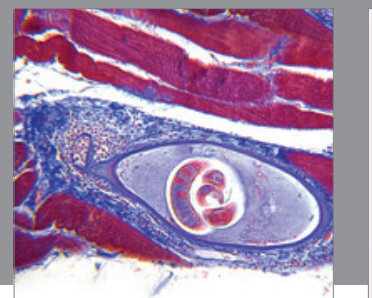

Gastroenterology

Research and Practice
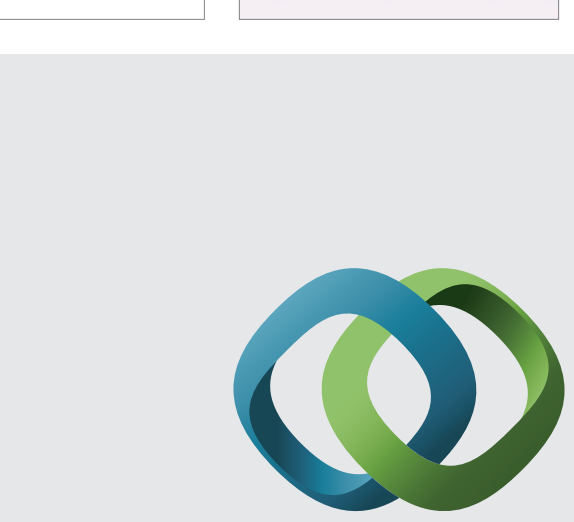

\section{Hindawi}

Submit your manuscripts at

http://www.hindawi.com
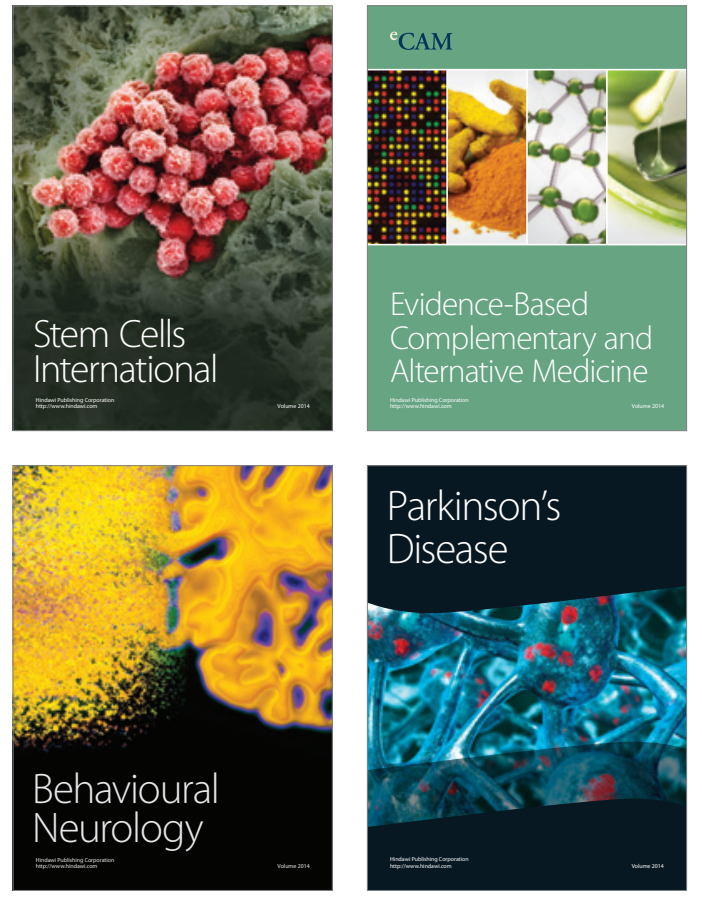
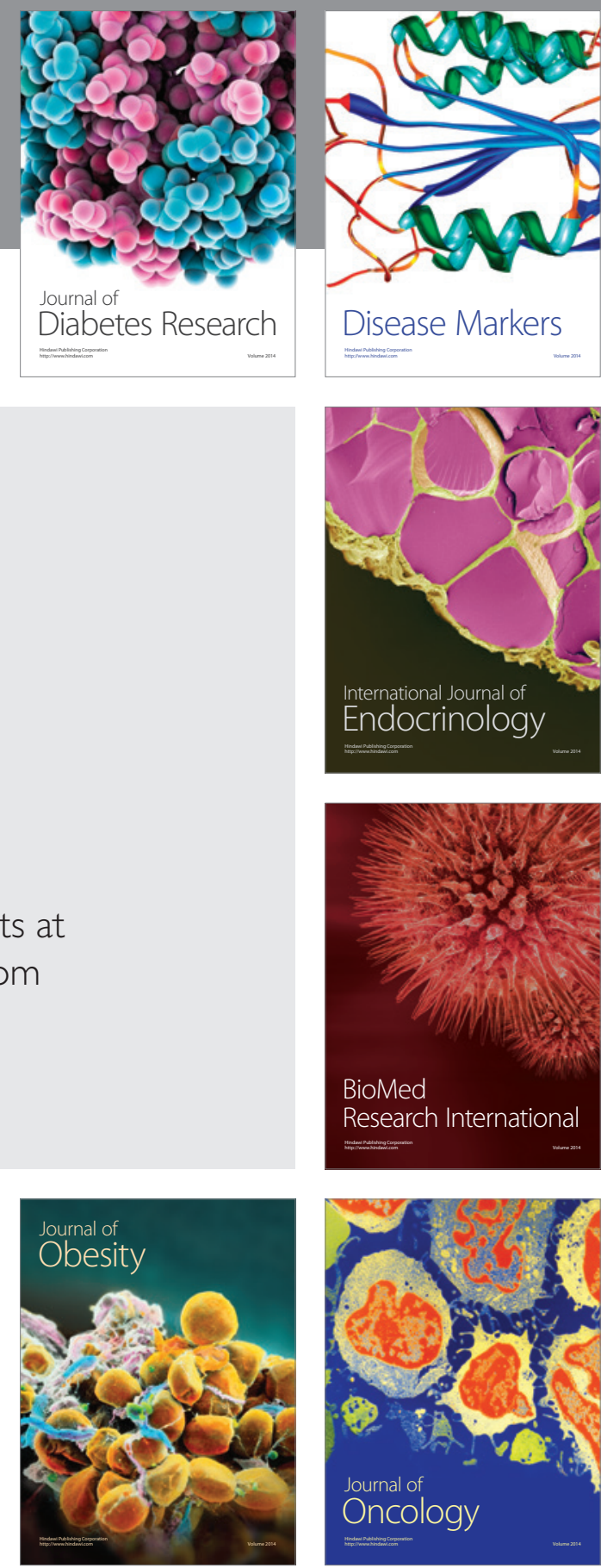

Disease Markers
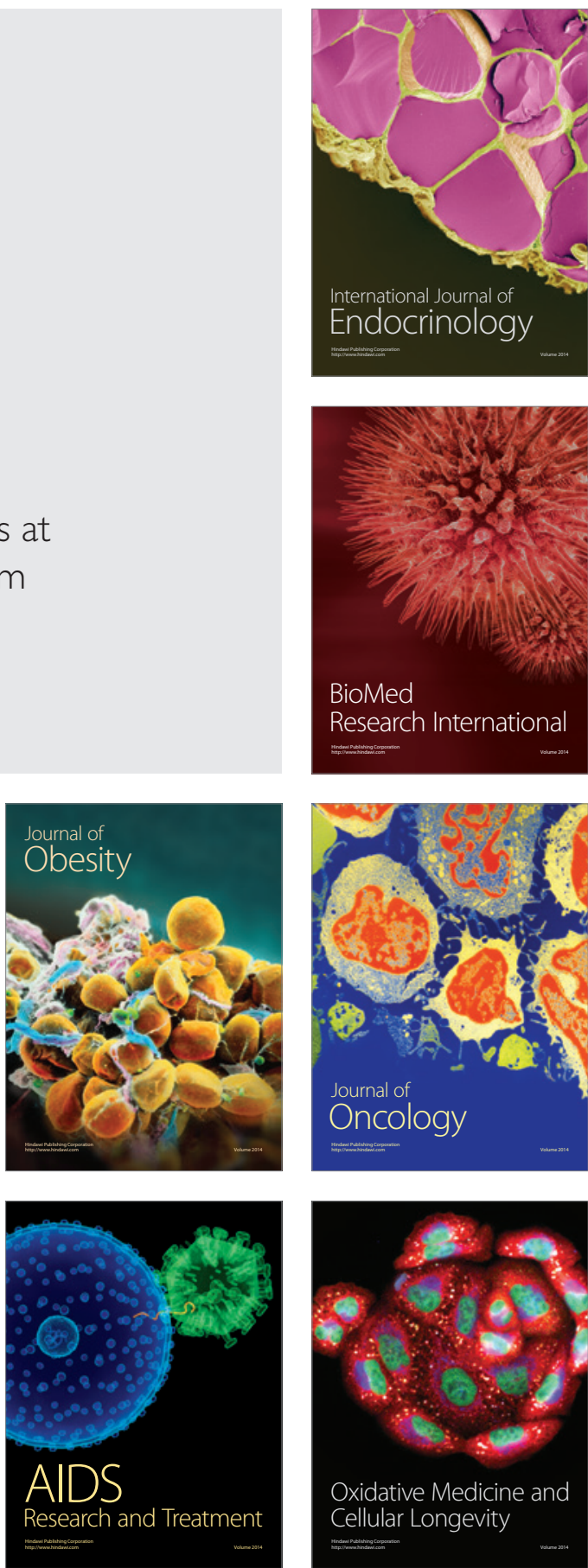